\title{
Trophic role of large benthic sulfur bacteria in mangrove sediment
}

\author{
Pierre-Yves Pascal ${ }^{1, *}$, Stanislas Dubois ${ }^{2}$, Henricus T. S. Boschker ${ }^{3}$, Olivier Gros ${ }^{1}$ \\ ${ }^{1}$ Département de Biologie, Université des Antilles et de la Guyane, UMR 7138 UPMC-CNRS-MNHN-IRD, \\ Equipe ‘biologie de la mangrove', UFR des Sciences Exactes et Naturelles, BP 592, 97159 Pointe-à-Pitre, Guadeloupe, France \\ ${ }^{2}$ IFREMER, DYNECO Laboratoire d'Ecologie Benthique, 29280 Plouzané, France \\ ${ }^{3}$ Royal Netherlands Institute of Sea Research (NIOZ), PO Box 140, 4400 AC Yerseke, The Netherlands
}

\begin{abstract}
Large filamentous sulfur-oxidizing bacteria belonging to the Beggiatoacae family can cover large portions of shallow marine sediments surrounding mangroves in Guadeloupe (French West Indies). In order to assess the importance of Beggiatoa mats as an infaunal food source, observations were conducted of the area within mats and at increasing distances from mats. We used natural isotopic compositions and a ${ }^{13} \mathrm{C}$ enrichment study. Both revealed an ingestion of bacterial mats by associated meiofauna, dominated by rotifers and to a smaller extent by small polychaetes and nematodes. Compared to adjacent sites, sediment covered by bacterial mats presented a higher abundance of diatoms, whereas the total biomass of bacteria did not vary. This constant bacterial abundance suggests that the proportion of organic matter represented by sulfur bacteria is limited compared to the fraction of total bacteria. There was no significant difference in infaunal abundance in mats, suggesting that the availability of this chemosynthetic food resource had a limited local effect. Grazers presented a $\delta^{13} \mathrm{C}$ value increasing with distance from the mat. However, isotopic composition of phospholipid-derived fatty acids specific for diatoms and bacteria revealed that this change is related to modifications of $\delta^{13} \mathrm{C}$ dietary components rather than to changes in diet composition. These complementary methods revealed that the occurrence of sulfur-oxidizing bacterial mats does not necessarily affect grazer abundance and importance of bacteria in their diet. Despite its wide occurrence, Beggiatoa mats would consequently have a minor influence on the structure of the mangrove food web.
\end{abstract}

KEY WORDS: Beggiatoa - Mangrove - Benthic food web - Sulfur bacteria - Meiofauna . Nematode $\cdot$ Rotifers $\cdot$ Stable isotope

\section{INTRODUCTION}

Bacteria are very important for the structure and functioning of all ecosystems due to their role in organic matter degradation and nutrient cycling. Bacteria can also be grazed and may play a major role in food webs as a food source (Sherr et al. 1987). This trophic role has been well established in pelagic environments, but, due to technical difficulties, the trophic role of bacteria is less well known in benthic systems (Kemp 1990). Outside of hydrothermal vent systems, studies focusing on the benthic bacterial compartment suggest that grazing is $<30 \%$ of the bacterial production in several marine environments such as intertidal mudflats (van Oevelen et al. 2006a, Pascal et al. 2009), shallow-water sands (Sundbäck et al. 1996) and deep-sea sediments (Gontikaki et al. 2011). The bacterial contribution to grazers' diet has also received little attention. This role is potentially limited as meiofauna would derive $<10 \%$ of their total carbon demand from bacteria in estuarine (van Oevelen et al. 2006a,b) and deep-sea environments (Gontikaki et al. 2011). The majority of studies suggest a role $<11 \%$ for macrofauna (van Oevelen et al. 
$2006 b)$, even in cases where a contribution of $50 \%$ was assessed for deep-sea macrofauna (Gontikaki et al. 2011). Previous grazing experiments performed simultaneously with dual-labeled food items (bacteria and diatoms) allowed the evaluation of ingestion selectivity by meio- and macrograzers; small meiofauna appeared to have a better selection efficiency due to their size and to preferentially ingest benthic microalgae as compared to less selective macrofauna (Pascal et al. 2008, 2013).

Several reasons potentially explain why bacteria do not constitute a major food resource and are not preferentially ingested by benthic browsers. Firstly, bacteria may lack essential components such as fatty acids that are present in diatoms and other microalgae (Zhukova \& Kharlamenko 1999). Secondly, bacteria and diatoms can differ in their spatial distribution and ultimately in their availability. Most studies have been performed in the intertidal environment, with benthic microalgae concentrated at the air-sediment interface during low tide, whereas bacteria are distributed more homogenously over a vertical gradient (Joint et al. 1982). Finally, most benthic bacteria are attached to sediment particles, in contrast to benthic microalgae, and feeding on microalgal biofilm would hence save energy by eliminating the need to (1) select food particles, for selective feeders, or (2) reject non-digestible material, for non-selective feeders. In contrast, feeding on bacteria would cost more energy for all grazer feeding modes.

As they form filaments reaching $200 \mu \mathrm{m}$ in diameter, the white sulfur-oxidizing bacteria belonging to the family Beggiatoaceae are among the largest prokaryotic organisms (Larkin et al. 1994). High concentrations of sulfide are produced in their habitat, and Beggiatoa cells obtain their energy from the oxidation of sulfide to sulfate. They can also produce elemental sulfur, stored as internal granules that are located mostly in the periplasm, explaining their white appearance (Schulz \& Jørgensen 2001). These bacteria inhabit the interface between anoxic sediments and oxic water and form mats that can reach $3 \mathrm{~cm}$ in thickness, are characterized by a patchy spatial distribution (Lloyd et al. 2010) and are typically located in quiet waters, in sediment with high organic matter loading or at sulfide seeps (Montagna \& Spies 1985). They are found in a large variety of freshwater as well as marine environments: in deepsea mud volcanoes and hydrothermal vents, around seeps of hydrocarbons and methane and below productive upwelling areas, and they have also been observed in shallow waters in polar (Van Gaever et al. 2006) and temperate (Fenchel \& Bernard 1995) environments, where they have been regarded as an indicator of organic enrichment (Elliott et al. 2006).

Beggiatoa are highly vacuolated and represent a small amount of dry matter (Bernard \& Fenchel 1995). Despite this apparently unfavorable characteristic, Beggiatoa seem to play an important role in the food web, as many protozoan species depend on sulfur-oxidizing bacteria for food; ciliates are assumed to be the main grazers of Beggiatoa (Bernard \& Fenchel 1995). Isotopic composition and high abundances of meiofaunal grazers in bacterial mats both suggest that sulfur bacteria are ingested in numerous deep-sea environments (Spies \& DesMarais 1983, Van Gaever et al. 2006, Pape et al. 2011). In contrast to deep-sea environments, the importance of bacterial mats for meio- and macrofauna in coastal food webs remains to be investigated (Bernard \& Fenchel 1995).

The aim of the present study was to determine if bacterial consumption by benthic organisms was increased when bacteria were concentrated in a Beggiatoa mat. The importance of bacteria as a potential food source for meio- and macrofauna was estimated here in a Caribbean mangrove forest using complementary methods. Abundance of infauna was evaluated, as well as natural carbon and nitrogen isotopic composition of potential grazers and their food source, along a spatial gradient of increasing distance from Beggiatoa mats. ${ }^{13} \mathrm{C}$ enrichments were made to enhance differences in isotopic compositions between the Beggiatoa mat and other food items. To our knowledge, this study is the first observation of Beggiatoa in mangrove environments. Due to their fragility, most meiofaunal taxa do not withstand sieving, fixation, or freezing techniques. However, permanent access to the study site allowed us to work with living animals and to consider those organisms largely neglected in food web studies.

\section{MATERIALS AND METHODS}

\section{Study area}

'Manche à eau' is a small tropical lagoon connected to the marine channel 'Rivière Salée' separating the 2 main islands of Guadeloupe (French West Indies) (Fig. 1). In this lagoon, tides are semidiurnal, with a mean tidal amplitude of $30 \mathrm{~cm}$ (tide gauge of Pointeà-Pitre, REFMAR ${ }^{\circledR}$ ). Temperature and salinity at below $0.5 \mathrm{~m}$ depth are relatively constant, with average values of $28^{\circ} \mathrm{C}$ and 35 , respectively. 


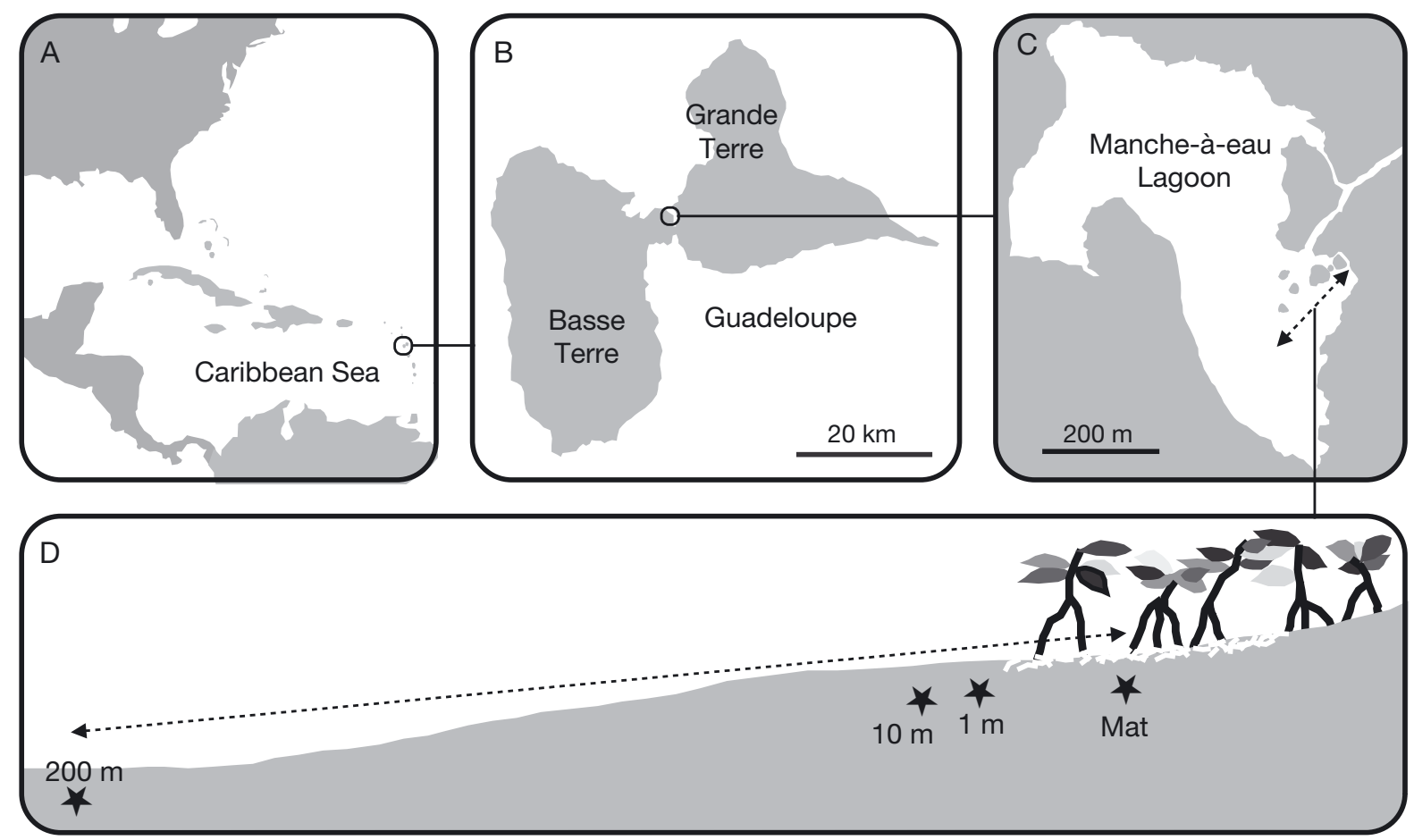

Fig. 1. (A) Location of Guadeloupe Island in the Caribbean Sea, (B) location of Manche-à-eau lagoon on Guadeloupe, (C) location of sampling transect and (D) schematic view of 4 sampling points along the transect, i.e. inside Beggiatoa mats and 1, 10 and $200 \mathrm{~m}$ away from mats (not drawn to scale)

The lagoon is bordered by a mangrove forest dominated by Rhizophora mangle. The sediment $(<1 \mathrm{~m}$ depth) between mangrove tree roots is anoxic and contains high sulfide concentrations (Maurin 2009). In some places, the sediment is covered by large patches of dense and conspicuous (20 to $60 \mu \mathrm{m}$ diameter) filamentous white sulfur bacteria, visible with the naked eye (Fig. 2, almost exclusively large Beggiatoa spp.). The size of these bacterial patches is temporally highly variable, with a diameter measuring from a few centimeters to several meters. High numbers of interstitial organisms such as ciliates, nematodes and turbellarians are associated with the mats.

Samples were collected by snorkeling in October 2011 at 4 different locations along a transect: inside a Beggiatoa mat (hereafter called $0 \mathrm{~m}$ station) and 1, 10 and $200 \mathrm{~m}$ away from the mats. Water depth along the transect ranged between $0.5 \mathrm{~m}$ (at the mat) and $2 \mathrm{~m}$ (200 m away) (Fig. 1). When collected, bacterial patches measured approximately $1 \mathrm{~m}$ width and were located $1 \mathrm{~m}$ away from the edge of the mangrove forest. At each location, 3 replicate samples were randomly collected. For stable isotope and abundance analyses, each sample consisted of 10 pooled cores of the $0-1 \mathrm{~cm}$ layer, collected with a

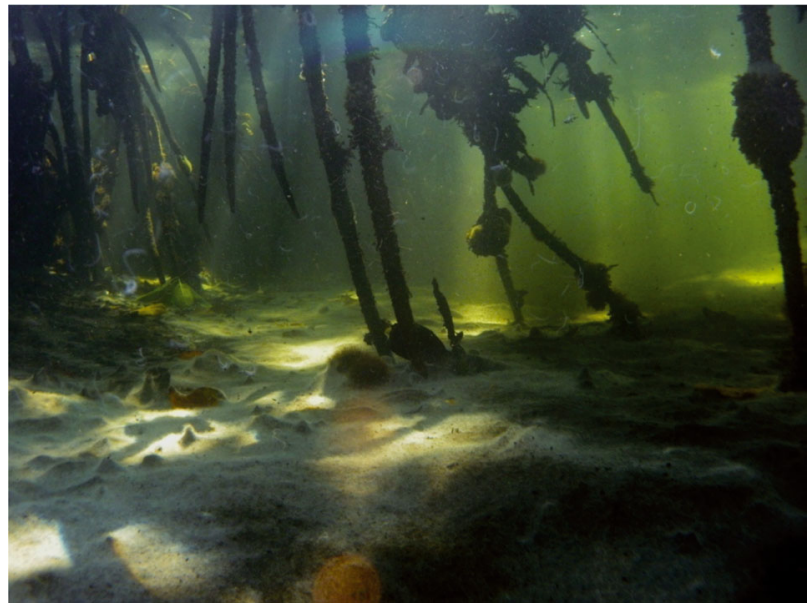

Fig. 2. Mats of white benthic filamentous sulfur bacteria between mangrove tree roots (water depth $=1 \mathrm{~m}$ )

syringe pushed gently into the sediment to avoid sediment suspension (inside core diameter $=5.5 \mathrm{~cm}$ ). For abundance of rotifers, polychaetes, copepods and nematodes, each sample was sieved and the fraction remaining on $63 \mu \mathrm{m}$ mesh was separated equally into different aliquots using a Motoda splitting box (Motoda 1959). This protocol allows reporting results per unit surface area. 


\section{Species identification}

The most abundant meiofaunal species were isolated and gathered according to morphology. When morphological traits were inconspicuous using a dissecting scope, species were pooled. This study consequently integrates different taxonomic levels. Abundant colonial ciliates were identified as the family Vorticellidae (hereafter called vorticel). Nematodes and copepods were identified to phylum and subclass levels, respectively. Rotifers and gnathostomulida species were identified using morphological traits as Rotaria spp. and Haplognathia ruberrima. The 2 abundant platyhelminth species were identified using molecular approaches as Macrostomum sp. and Polycanthus sp.; DNA was extracted from freshly collected specimens using DNeasy blood and tissue kit (Qiagen) according to the manufacturer's instructions. The 18S rDNA markers were amplified using primers $1 \mathrm{~F}$ and 5R. PCR products were purified with QIAquick PCR purification kit (Qiagen) and directly sequenced by Genoscreen. The 18S rDNA gene sequences obtained were compared with the $\mathrm{Na}$ tional Center of Biotechnology Information (NCBI) (www.ncbi.nlm.nih.gov).

\section{Abundance and isotopic composition}

Sediment was freeze-dried, phospholipid-derived fatty acids (PLFA) were extracted and their isotopic composition was determined using a gas-chromatograph combustion-interface isotope-ratio mass spectrometer (GC-C-IRMS) following the protocol in Boschker et al. (1999). Concentrations and $\delta^{13} \mathrm{C}$ PLFA specific to bacteria (i14:0, i15:0, ai15:0, i16:0, C18:

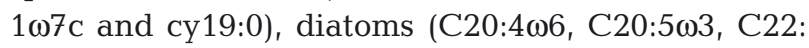

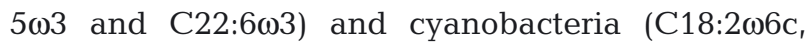
$\mathrm{C} 18: 3 \omega 3, \mathrm{C} 18: 4 \omega 3)$ were used to estimate the relative contribution of these groups to the total PLFA pool and their weighted-average $\delta^{13} \mathrm{C}$ composition. The carbon content of bacteria and diatoms was evaluated using carbon PLFA/carbon biomass ratios of 0.056 and 0.035, respectively (Boschker \& Middelburg 2002).

Polychaetes, nematodes, copepods and rotifers were extracted from sediment using Ludox HS40 (de Jonge \& Bouwman 1977). For abundance evaluations, samples were fixed with $2 \%$ formalin and stained with Rose Bengal. For stable isotope analysis, sediment was frozen and 150 Ceratocephale sp., 700 nematodes, 100 copepods and 1500 rotifers were haphazardly removed from each sample. Several protocols were applied to extract potential prey and infauna from the sediment. Sediment sampled from Beggiatoa mats was allowed to settle a few minutes in the laboratory until a new bacterial biofilm formed; diatoms and filamentous sulfur-oxidizing bacteria were individually picked alive and cleaned of debris under a dissecting microscope. A similar protocol was used to collect 150 Macrostomum sp., 60 Haplognathia ruberrima and 2000 vorticels. In sediment without bacterial mats, white specimens of Polycanthus sp. were easily identified against the dark sediment, and, for each sample, $\geq 150$ specimens were live picked using a glass pipette. Macrofaunal specimens of ragged sea hare (Bursatella leachii) were collected in the field and starved overnight to clear gut contents. For each sample, 12 specimens were homogenized using a blender, freeze-dried, and a fraction of the sample was used for stable isotope analyses. The $\mathrm{C} / \mathrm{N}$ ratio and isotopic composition of bulk sediment containing bacteria and diatoms was determined for each sample from untreated sub-samples for ${ }^{15} \mathrm{~N}$ content and from acid $(1 \mathrm{M} \mathrm{HCl})$-treated sub-samples for ${ }^{13} \mathrm{C}$ content. Using mass-balance equations, isotopic compositions and abundances of bacteria and diatoms evaluated with PLFA were used to calculate isotopic composition of detritus free of bacteria and diatoms.

Isotope samples were analyzed at the Isotope Facility at the University of California, Davis, using an elemental-analyzer isotope ratio mass spectrometer. Samples were reported relative to the standards atmospheric $\mathrm{N}_{2}$ and Vienna PeeDee Belemnite carbon. Stable isotope values are reported in $\delta$ notation (in \%):

$$
\delta^{13} \mathrm{C} \text { or } \delta^{15} \mathrm{~N}=\left[\left(R_{\text {sample }} / R_{\text {standard }}\right)-1\right] \times 10^{3}
$$

where $R$ is ${ }^{13} \mathrm{C} /{ }^{12} \mathrm{C}$ or ${ }^{15} \mathrm{~N} /{ }^{14} \mathrm{~N}$, respectively. Using standards, analytical precision was estimated to $0.2 \%$ for both ${ }^{13} \mathrm{C}$ and ${ }^{15} \mathrm{~N}$.

\section{Enrichment experiment}

To further investigate the consumption of Beggiatoa by sediment fauna, we designed a ${ }^{13} \mathrm{C}$-labeling experiment where chemoautotrophic bacterial mats were selectively labeled in the dark. Sediment from the bacterial mat environment was sampled in January 2012 and placed in 3 circular mesocosms (internal diameter $=23.5 \mathrm{~cm}$ with a sediment height of $25 \mathrm{~cm}$ ). A recirculating system of 41 water allowed sediment of each tank to be covered by $1 \mathrm{~cm}$ of oxygenated lamellar running water. $\mathrm{NaH}^{13} \mathrm{CO}_{3}(>99 \%$ 
${ }^{13} \mathrm{C}$-enriched) was added to reach a final concentration of $1 \mathrm{~g} \mathrm{~m}^{-2}$ (Middelburg et al. 2000). Incubations were realized in the dark, at $25^{\circ} \mathrm{C}$, salinity 35 and during $4 \mathrm{~d}$. At the end of the incubation, the isotopic compositions of bacteria, nematodes and rotifers were measured with methods previously described.

\section{Data analyses}

One-way analysis of variance (ANOVA) was used to test for differences in the $\mathrm{C} / \mathrm{N}$ ratio of sediment, biomass of bacteria and diatoms and abundance of meiofauna (rotifers, polychaetes, copepods and nematodes). Normality of residuals was tested using Shapiro-Wilk tests before performing ANOVA. When overall ANOVA tests were significant, Tukey tests were used for post hoc comparisons. Unless specified, values are presented as means \pm standard deviations (SD).

A Bayesian isotopic mixing model was used to determine possible contributions of different food items to the diet of infauna found in Beggiatoa mats. Isotopic compositions of diatoms and bulk organic matter from sediment were not discriminated from $\delta^{13} \mathrm{C}$ compositions and were averaged into one food source called BOM (bulk organic matter). SIAR (stable isotope analysis in $\mathrm{R}_{i}$ Parnell et al. 2010) incorporates the variability of consumers and trophic enrichment factors (TEFs) to produce a mean and a $95 \%$ confidence interval of the percent contribution of each source to a consumer. As Haplognathia ruberrima graze mainly, if not exclusively on Beggiatoa mats (Pascal et al. in press), we used the a posteriori isotopic signature of the gnathostomulids to calculate a TEF of $-1.5 \pm 1.0 \%$ for $\delta^{13} \mathrm{C}$ of Beggiatoa bacteria. For the $\delta^{13} \mathrm{C}$ of BOM, a TEF of $1.1 \pm 0.3 \%$ (McCutchan et al. 2003) and, for the $\delta^{15} \mathrm{~N}$ of all food sources, a TEF of $3.4 \pm 1.1 \%$ were used (Minagawa \& Wada 1984).

\section{RESULTS}

\section{The Beggiatoa mat environment}

One species of Platyhelminth was identified as Macrostomum sp., as it shows $99.2 \%$ similarity with Macrostomum lignano (550 bp), and the other species was idenfified as Polycanthus sp., as it presents $98.0 \%$ similarity with Polycanthus torosus (500 bp). Using morphological traits, the most abun- dant polychaete was identified as Ceratocephale sp. (C. Glasby pers. comm.), which was supported by the 18S rDNA sequence analysis.

Individual weights of infauna were derived from stable isotope samples (Table 1). In the surficial sediment, mean percentage contributions of PLFA specific for bacteria, diatoms and cyanobacteria are presented in Table 2. Expressed in abundances per surface unit, the biomass of bacteria was higher than the biomass of algae (Fig. 3). Meiofauna presented highly variable abundances in the mats' environment (Fig. 4). Among meiofauna enumerated in the samples, rotifers were dominant in biomass (101.7 \pm $\left.96.1 \mathrm{mg} \mathrm{C} \mathrm{m}^{-2}\right)$, followed by Ceratocephale sp. (71.0 $\left.\pm 75.6 \mathrm{mg} \mathrm{C} \mathrm{m}^{-2}\right)$, nematodes $\left(15.4 \pm 9.1 \mathrm{mg} \mathrm{C} \mathrm{m}^{-2}\right)$ and copepods $\left(1.5 \pm 2.5 \mathrm{mg} \mathrm{C} \mathrm{m}^{-2}\right)$.

Of all food sources, Beggiatoa were the most depleted in ${ }^{13} \mathrm{C}$, whereas diatoms were the most enriched (Fig. 5). Sediment detritus had a carbon isotopic composition close to that of diatoms, and, among potential grazers, Haplognathia ruberrima was the most ${ }^{13} \mathrm{C}$ depleted, whereas $B$. leachii was the most enriched. All other meiofaunal members presented a $\delta^{13} \mathrm{C}$ varying between -26.2 and $-21.9 \%$. Diatoms were the food source with the lowest $\delta^{15} \mathrm{~N}$ value, while detritus and Beggiatoa were more enriched in ${ }^{15} \mathrm{~N}$. All fauna were enriched in ${ }^{15} \mathrm{~N}$ compared to the food sources, with $\delta^{13} \mathrm{C}$ isotope signatures ranging between 4.06 and $8.94 \%$ (Fig. 5).

Table 1. Individual infaunal weights derived from the weights of stable isotope samples

\begin{tabular}{|lcc|}
\hline & $\begin{array}{c}\text { Number of speci- } \\
\text { mens examined } \\
\text { (triplicate samples) }\end{array}$ & $\begin{array}{c}\text { Weight } \\
\text { per } \\
\text { specimen }\end{array}$ \\
\hline Rotifers & $3 \times 1500$ & $158 \pm 70 \mathrm{ng}$ \\
Copepods & $3 \times 100$ & $685 \pm 233 \mathrm{ng}$ \\
Nematodes & $3 \times 700$ & $789 \pm 241 \mathrm{ng}$ \\
Macrostomum sp. & $3 \times 150$ & $2.79 \pm 0.12 \mu \mathrm{g}$ \\
Ceratocephale sp. & $3 \times 100$ & $2.98 \pm 0.86 \mu \mathrm{g}$ \\
Haplognathia ruberrima & $3 \times 60$ & $3.94 \pm 2.65 \mu \mathrm{g}$ \\
Bursatella leachii & $3 \times 12$ & $2.02 \pm 0.33 \mathrm{~g}$ \\
\hline
\end{tabular}

Table 2. Contributions of phospholipid-derived fatty acids specific for bacteria, diatoms and cyanobacteria to total fatty acid methyl esters along transect stations $(\%$, means $\pm \mathrm{SD}, \mathrm{n}=3$ )

\begin{tabular}{|lrrrr|}
\hline & Mat & \multicolumn{1}{c}{$1 \mathrm{~m}$} & \multicolumn{1}{c|}{$10 \mathrm{~m}$} & \multicolumn{1}{c|}{$200 \mathrm{~m}$} \\
\hline Bacteria & $25.1 \pm 2.0$ & $27.1 \pm 2.6$ & $21.1 \pm 3.2$ & $25.1 \pm 0.4$ \\
Diatoms & $8.1 \pm 2.0$ & $6.5 \pm 0.8$ & $6.6 \pm 1.3$ & $3.5 \pm 1.0$ \\
Cyanobacteria & $2.4 \pm 0.3$ & $2.5 \pm 0.2$ & $2.2 \pm 0.2$ & $1.7 \pm 0.0$ \\
\hline
\end{tabular}



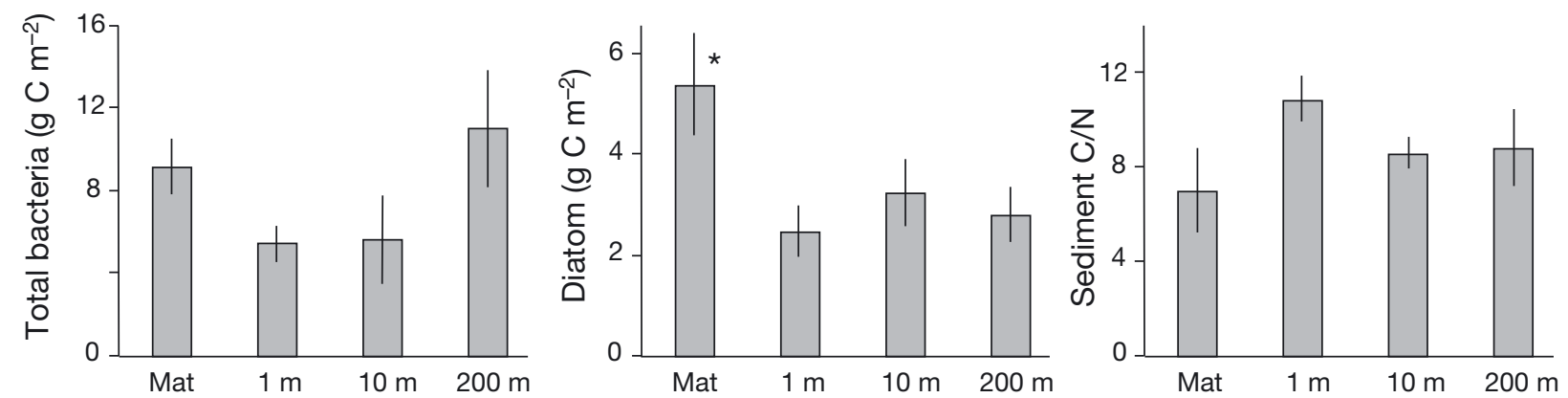

Fig. 3. Biomass of bacteria and diatoms (in $\mathrm{g} \mathrm{C} \mathrm{m}^{-2}$ ) and carbon/nitrogen ratio of surficial sediment $(1 \mathrm{~cm})$ along transect stations (means $\pm \mathrm{SD}, \mathrm{n}=3$ ). *: significant differences $(\mathrm{p}<0.01$; ANOVA; Tukey test)
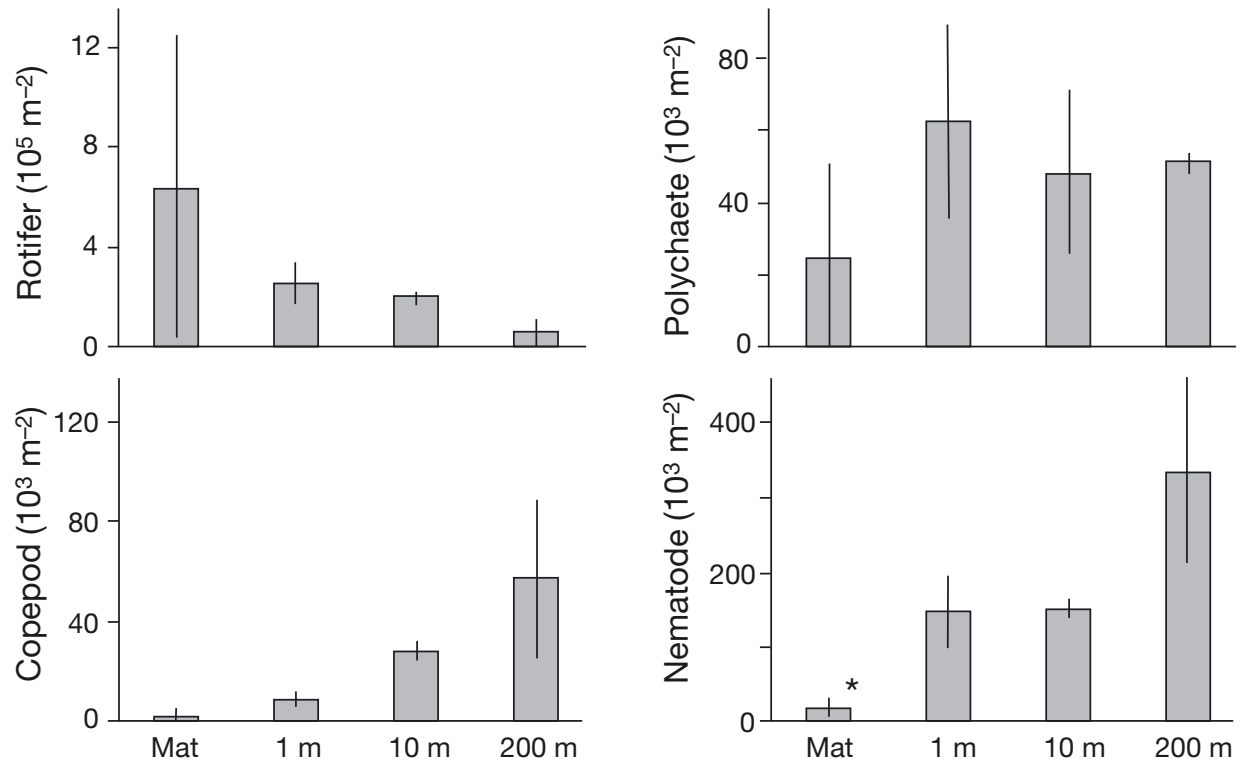

Fig. 4. Abundances of meiofauna (rotifers in $10^{5} \mathrm{~m}^{-2}$ and polychaetes, copepods and nematodes in $10^{3} \mathrm{~m}^{-2}$ ) in surficial sediment $(1 \mathrm{~cm})$ along transect stations (means $\pm \mathrm{SD}$, $\mathrm{n}=3$ ). *: significant differences $(\mathrm{p}<0.01$; ANOVA; Tukey test)
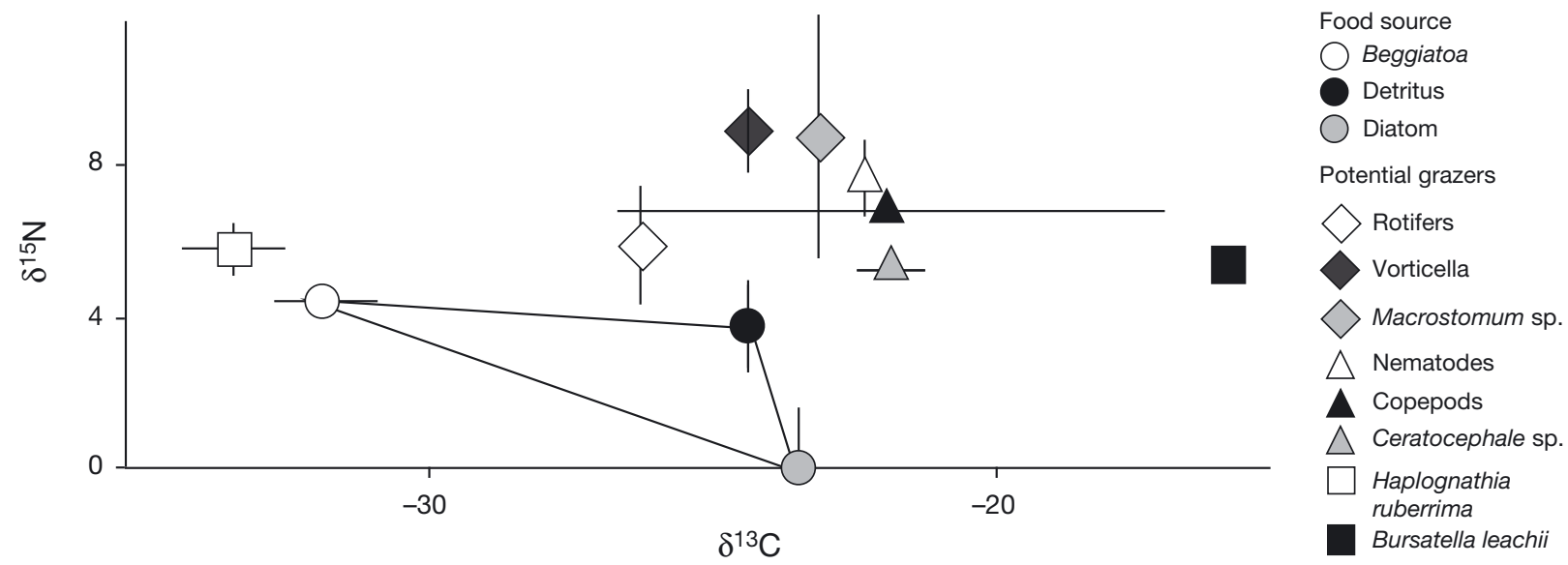

Fig. 5. Natural isotopic composition $\left(\delta^{13} \mathrm{C}\right.$ and $\left.\delta^{15} \mathrm{~N}\right)$ of food sources (Beggiatoa, diatoms, bulk sediment [detritus]) and meiofaunal (rotifer, vorticel, Macrostomum sp., nematode, copepod, Ceratocephale sp., Haplognathia ruberrima) and macrofaunal

(Bursatella leachii) potential grazers. Means $\left( \pm \mathrm{SD}_{i} \mathrm{n}=3\right.$ ) are reported 
The diet composition of $B$. leachii could not be resolved based on isotope compositions. SIAR outputs suggested that all other meiofaunal grazers were ingesting Beggiatoa, but in different proportions. Grazers with the highest contribution of the bacterial mats in their diet were H. rubberima, copepods, rotifers and nematodes, with respective mean percentages of $86,41,28$ and $22 \%$. Ceratocephale sp., vorticels and Macrostomum sp. ingested less Beggiatoa material with respective mean percentages of 16, 12 and $5 \%$ (Fig. 6).

Complementary enrichment experiments with $\mathrm{NaH}^{13} \mathrm{CO}_{3}$ led to ${ }^{13} \mathrm{C}$ enrichment of Beggiatoa with $\delta^{13} \mathrm{C}$ increasing from -31.7 to $1693 \%$ (Table 3). Nematodes and rotifers incubated with these enriched bacteria both showed an increase in ${ }^{13} \mathrm{C}$ content. Isotopic compositions of potential grazers and food sources in ${ }^{13} \mathrm{C}$-enriched conditions were also used to run a SIAR mixing model. Model outputs with enrichment conditions confirmed a contribution of Beggiatoa in grazer diets. This contribution was analogous in enriched versus control conditions for nematodes ( 23 vs. $24 \%$ ) and rotifers ( 27 vs. $28 \%$ ). Similarly, contributions of other food items to the diet did not differ between control and enriched conditions (Table 3).

\section{Environments adjacent to Beggiatoa mats}

Along the transect at 1, 10 and $200 \mathrm{~m}$ from Beggiatoa mats, the total biomass of bacteria was not significantly affected by the presence of Beggiatoa mats (Fig. 3). Conversely, microalgal biomass was significantly higher in Beggiatoa mats than at all other stations (Fig. 3). Cyanobacteria were always less abundant than bacteria and diatoms (Table 2). Differences in detritus $\mathrm{C} / \mathrm{N}$ ratios were not significant between stations.

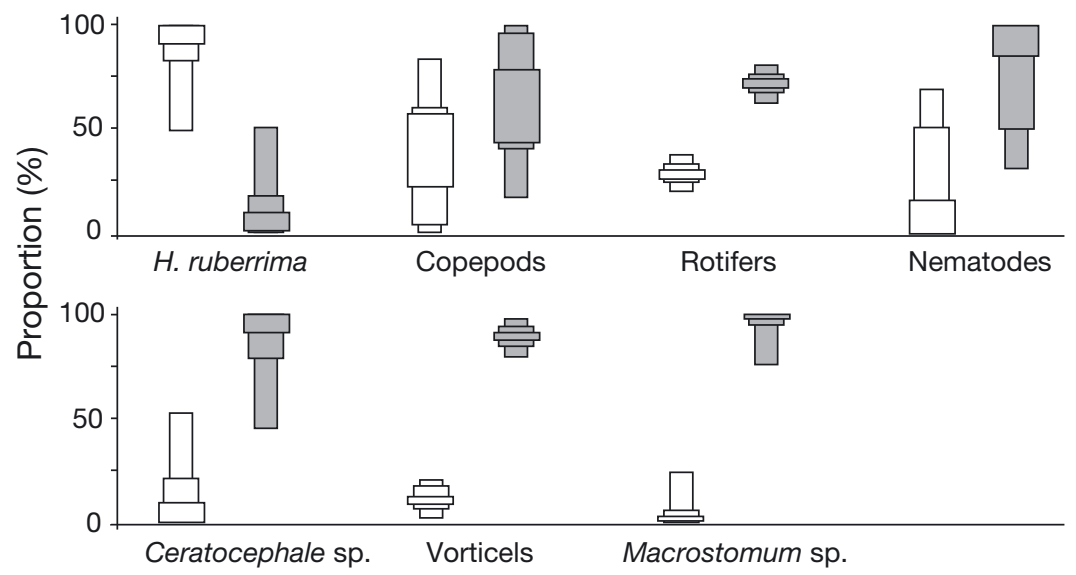

Table 3. Isotopic composition $\left(\delta^{13} \mathrm{C}\right)$ in the enrichment experiment (means $\pm \mathrm{SD}$ ). Mean contributions (\%) and $95 \%$ confidence intervals of different food items (Beggiatoa, diatoms and detritus) to the diet of nematodes and rotifers based on the SIAR (stable isotope analysis in R) mixing model

\begin{tabular}{|lcc|}
\hline & Control & $\begin{array}{c}\text { Enrichment } \\
\text { experiment }\end{array}$ \\
\hline $\mathbf{\delta}^{\mathbf{1 3}} \mathbf{C}(\mathbf{\%})$ & & \\
Beggiatoa & $-31.7 \pm 0.9$ & $1693.2 \pm 275.5$ \\
Nematodes & $-22.3 \pm 0.3$ & $338.8 \pm 65.9$ \\
Rotifers & $-26.2 \pm 0.6$ & $389.3 \pm 95.9$ \\
Nematode diet composition (\%) & \\
Beggiatoa & $24(0-68)$ & $23(11-38)$ \\
Diatoms and detritus & $75(31-100)$ & $77(62-89)$ \\
Rotifer diet composition $\mathbf{( \% )}$ & \\
Beggiatoa & $28(18-38)$ & $27(6-51)$ \\
Diatoms and detritus & $71(61-81)$ & $72(49-94)$ \\
\hline
\end{tabular}

Abundances of nematodes and copepods tended to increase, whereas abundances of rotifers tended to decrease with increasing distance from mats. However, none of those differences were significant except that nematodes were significantly less abundant in mats (Fig. 4). The variability in rotifer, polychaete, copepod and nematode abundances was higher in mats, where SD reached $106 \%$ of the mean value. Individual biomasses of grazers were derived from weights of stable isotope samples and were not significantly different among stations for nematodes, copepods, Polycanthus sp., or Bursatella leachii. There was no clear trend in nitrogen isotopic composition of grazers along the transect (Fig. 7). Carbon isotopic compositions in all grazers decreased with increasing distances from mats (Fig. 7). The difference in grazer $\delta^{13} \mathrm{C}$ between $200 \mathrm{~m}$ and mat stations was higher for copepods $(9.3 \%$ ) and nematodes $(4.4 \%$ ) but was lower for B. leachii $(0.6 \%$ ) (Fig. 7). The isotopic composition of PLFA revealed gradual ${ }^{13} \mathrm{C}$ enrichment of both bacteria and diatoms along
Fig. 6. Contribution (\%) of different food items (white: Beggiatoa; grey: bulk organic matter) to the diet of meiofaunal grazers (the gnathostomulid Haplognathia ruberrima, copepods, rotifers, nematodes, the polychaete Ceratocephale sp., vorticels, the plathyhelminth Macrostomum sp.). Results were issued with the SIAR (stable isotope analysis in R) mixing model. For each source 95,75 and $25 \%$ credibility intervals of probability distributions were reported 

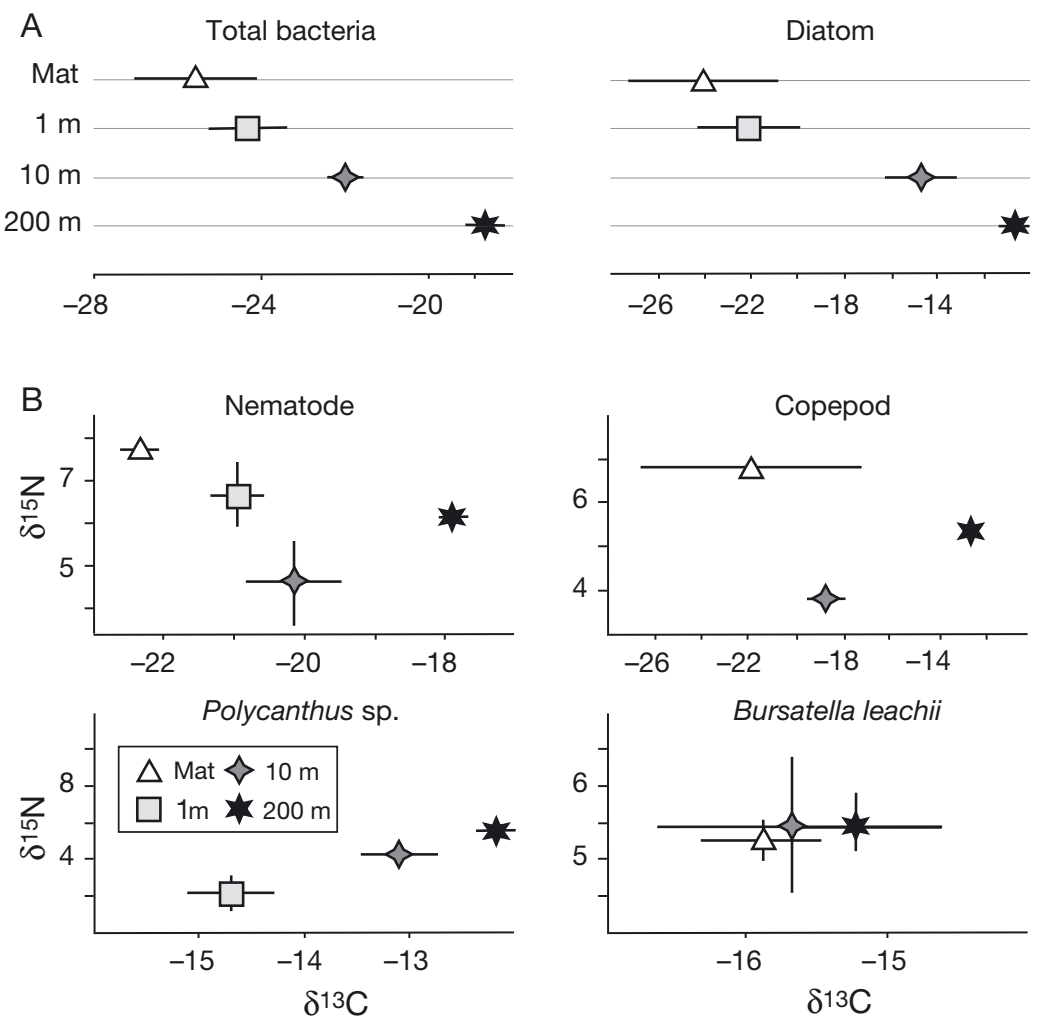

Fig. 7. Natural isotopic composition of (A) bacterial and algal phospholipidderived fatty acids $\left(\delta^{13} \mathrm{C}\right)$ and $(\mathrm{B})$ potential grazers $\left(\delta^{13} \mathrm{C}\right.$ and $\delta^{15} \mathrm{~N}$ of nematodes, copepods, Polycanthus sp. and Bursatella leachii), along transect stations (means $\pm \mathrm{SD}, \mathrm{n}=3$ )

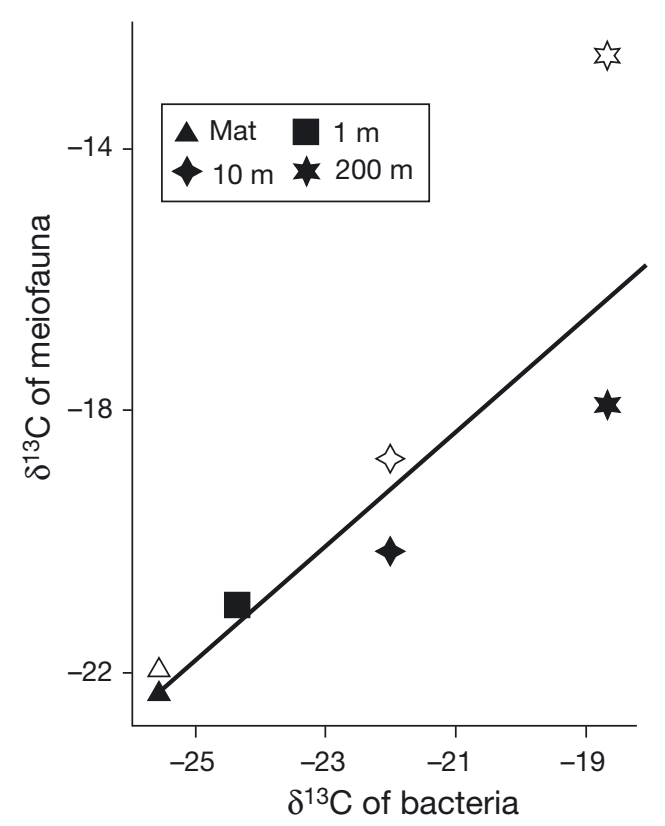

Fig. 8. Carbon natural isotopic compositions of meiofauna (white symbols: copepods; black symbols: nematodes) according to the $\delta^{13} \mathrm{C}$ of bacterial phospholipid-derived fatty acids along transect stations. The theoretical line represents the variation in identical amounts of bacteria and meiofauna the transect away from the mat (Fig. 7). The decrease in $\delta^{13} \mathrm{C}$ from the $200 \mathrm{~m}$ station to the mat station was smaller for bacteria (6.9\%) than for algae $\left(13.3 \%\right.$ ) (Fig. 7 ). The $\delta^{13} \mathrm{C}$ of bacteria and of meiofaunal grazers covaried; both values showing similar increases with respect to distances from the Beggiatoa mat (Fig. 8).

\section{DISCUSSION}

The simplest approach to determine trophic linkages between bacteria and grazers is to compare their respective distributions in natural environments. Interpretation of these results can be difficult as grazers potentially affect bacterial dynamics through processes other than grazing. For instance, nematodes have been reported to favor development of Beggiatoa mats as they increase oxygen penetration and nutrient diffusion into bacterial mats (Salvadó et al. 2004). The use of stable isotopes is an increasingly applied alternative approach to investigate trophic interactions. The full potential of stable isotopes is tightly linked to the discrimination of potential food sources in terms of isotopic compositions. In the studied mangrove environment, Beggiatoa are distinct from diatoms as they present a lower $\delta^{13} \mathrm{C}$ due to their specific pathways for carbon metabolism (Güde et al. 1981). One way to increase the power of stable isotope techniques is to artificially enhance differences in isotopic compositions of food items for better determination of their contribution in food webs (van Oevelen et al. 2006a,b, Galván et al. 2008). In the present study, the sediment contained mangrove tree detritus, mostly coming from Rhizophora mangle bordering the mangrove forest seaward, and this tree material is depleted in ${ }^{13} \mathrm{C}$ with values reaching $-30 \%$ (A. Mothet pers. comm.). The $\delta^{13} \mathrm{C}$ of mat bulk sediment does not express variability in the composition of each detrital compound as it presents an average value of $-24 \%$. Selective ingestion of depleted detritus by browsers would overestimate the contribution of depleted Beggiatoa in their diet. To increase the power of discrimination among sources, an enrichment experiment was performed in the dark to modify the isotopic composition of bacteria, but not of diatoms and detritus. 
Natural isotopic compositions revealed that Beggiatoa was ingested by all studied grazers, with a variable contribution of this food item according to infaunal species. For 2 of those grazers, this conclusion was corroborated by the enrichment experiment, revealing similar contribution rates of Beggiatoa in their diets.

Meiofaunal dwelling in Beggiatoa mats was largely dominated in both abundance and biomass by rotifers. This dominance was observed throughout a year-round survey (Pascal et al. unpubl. data). This result was unexpected as most species of benthic rotifers were described in freshwater and limnoterrestrial environments (Schmid-Araya 1998), but rotifers in marine environments have received far less attention. Rotifer species were reported in a hypersaline brine channel of Arctic sea ice, suggesting their ability to colonize extreme environments (Friedrich \& deSmet 2000). Their occasional occurrence in anoxic and sulfidic marine environments has previously been observed (Fenchel \& Riedl 1970, Bernard \& Fenchel 1995). More recently high rotifer abundances were observed at $800 \mathrm{~m}$ water depth colonizing surficial gas hydrates (Sommer et al. 2003, 2007), where oxidation of methane leads to the production of large amounts of sulfide, which ultimately favors the growth of sulfidic bacteria like Beggiatoa. Similar to deep-sea gas hydrates, rotifers in the present study dominated the meiofaunal community when sulfide concentrations were high and presented a high average abundance: $5.3 \times 10^{5}$ (Sommer et al. 2003) versus $6.4 \times 10^{5}$ ind. $\mathrm{m}^{-2}$ in the present study. However, other deep-sea investigations of methane seeps revealed absence (Pape et al. 2011) or marginal (Hauquier et al. 2011) density of rotifers. Guilini et al. (2012) considered that rotifers observed in the studies by Sommer et al. $(2003,2007)$ might have resulted from artificial contamination by tap water. Such contamination was unlikely in the present study as rotifer specimens were observed directly in untreated sediment. Sommer et al. (2007) suggested that high variations in rotifer abundances could be explained by migration between oxygenated surface sediment and deeper zones to escape predation by nematodes. Little is known about the feeding ecology of marine rotifers, and most species have a ventral ciliated field used to scrape the biofilm of bacteria, fungi and diatoms (Schmid-Araya 1998). Uptake of sulfur-oxidizing bacteria by rotifers in sulfidic environments has previously been suggested (Fenchel \& Riedl 1970), and their highest abundance in Beggiatoa mats has been explained by sulfur-oxidizing bacteria consumption
(Sommer et al. 2007). In our study, isotopic compositions under both natural abundance and enriched conditions suggested a substantial contribution of Beggiatoa in the rotifers' diet. Beggiatoa would not be an obligatory feeding resource as rotifers were found in environments adjacent to Beggiatoa mats where they may depend on organic carbon from the overlying water column (Sommer et al. 2007).

Polychaetes dwelling in Beggiatoa mats of mangrove sediments are members of the meiofauna, and their stable isotopic composition also suggests potential ingestion of sulfur-oxidizing bacteria. Consumption of filamentous sulfur-oxidizing bacteria from methane seeps by macrofaunal dorvilleid polychaetes was previously revealed by direct observation of gut content and stable isotope analysis (Levin \& Michener 2002).

Nematodes are the third dominant members of the meiofauna in Beggiatoa mats. Our stable isotope analyses in natural and enriched conditions supported the consumption of sulfur bacteria by the nematode community. According to previous investigations, nematodes are the dominant taxonomic group in shallow-sediment Beggiatoa mats (Montagna et al. 1989, Bernard \& Fenchel 1995), as well as in deep-sea environments (Van Gaever et al. 2006, Pape et al. 2011). Ingestion of filamentous sulfuroxidizing bacteria by nematodes has been observed (Bernard \& Fenchel 1995) and also revealed by their isotopic composition (Spies \& DesMarais 1983). At an Arctic mud volcano, the proliferation of a single species of nematodes in Beggiatoa mats was attributed to the feeding on sulfur bacteria, with a trophic specialization uncommon among meiofaunal organisms (Van Gaever et al. 2006).

Copepods usually represent $<1 \%$ of the total meiofauna in bacterial sulfide-oxidizing mats (Fenchel \& Riedl 1970, Bernard \& Fenchel 1995), whereas their dominance is higher in adjacent habitats (Montagna \& Spies 1985, Powell et al. 1986, Van Gaever et al. 2006, Sommer et al. 2007). Similarly, copepods presented lower abundances in the present study. This limited abundance of copepods is probably due to a low tolerance to anoxia and sulfide (Levin et al. 1991).

In sulfide seeps, groups of plathylminths, aschelminths and gnathostomulids constitute a high fraction of the meiofaunal community, whereas this contribution is limited in adjacent non-sulfidic sediments (Powell et al. 1986). Abundances of those groups were not evaluated in the present study, but their stable isotope compositions suggested a contribution of Beggiatoa to their diets. The high ${ }^{13} \mathrm{C}$ depletion of the 
gnathostomulidae Haplognathia ruberrima does not appear to be due to endo- or ectosymbioses with sulfur-oxidizing bacteria but to be related to selective ingestion of sulfur-oxidizing bacteria (Pascal et al. in press). Macrostomum lignano can easily be cultured with diatoms in experimental conditions (Ladurner et al. 2005), and this turbellarian species is a model organism classically used to investigate hermaphroditic reproduction, developmental biology and ageing (Schärer et al. 2004). Macrostomum spp. are not strictly herbivores as, in the present study, they were seen consuming large filamentous sulfur-oxidizing bacteria, and their stable isotope composition suggests this is not an uncommon feeding behavior (P. Y. Pascal pers. obs.).

The ragged sea hare Bursatella leachii is a key benthic component of the macrofaunal community of mangrove habitats. They have a daily rhythm and an aggregative distribution in shallow subtidal waters (Ramos et al. 1995). B. leachii is a generalist grazer of a wide variety of macroalgae and benthic cyanobacteria (Ramos et al. 1995). In the Manche à Eau system, their abundance was highly variable, with temporal peak densities showing individuals grazing upon Beggiatoa mats as well as surficial sediment in adjacent benthic environments (P. Y. Pascal pers. obs.). The very heavy $\delta^{13} \mathrm{C}$ signal of $B$. leachii revealed that this gastropod migrates and feeds outside the mangrove forest, given their more enriched $\delta^{13} \mathrm{C}$ composition (Finlay \& Kendall 2007). Sulfur bacteria may represent one of the potential food sources ingested by $B$. leachii but may possibly only be consumed ephemerally when this mollusk is swarming in the mangrove environment.

The variability in infaunal abundance in the studied mangrove mats was higher than in the adjacent sediments. Similarly, high variations in meiofaunal abundances have been revealed in other bacterial mats from seeps in coastal (Montagna \& Spies 1985) and deep-sea environments (Van Gaever et al. 2006). Our results supported the idea that sulfide systems are heterogeneous environments characterized by highly variable geochemistry.

Beggiatoa mat sediments were characterized by a higher abundance of diatoms than adjacent sediments. Most studies focusing on free-living sulfuroxidizing bacteria like Beggiatoa were done in deepsea environments where primary producers are absent. Bacterial mats in a coastal petroleum seep (15 m water depth) also present high chlorophyll $a$ concentrations, even if the dominance of phaeophytin $a$ indicates stressed and decaying microalgal populations (Montagna \& Spies 1985). Similarly, high abun- dances of diatoms were reported in sulfur-oxidizing bacterial mats in shallow-water (6.5 m water depth) sediments in Denmark (Bernard \& Fenchel 1995) and in deeper sediments (60 $\mathrm{m}$ water depth) in the Gulf of Mexico (Powell et al. 1986). These high abundances may reflect the tolerance of benthic diatoms to relatively high sulfide concentrations (Admiraal \& Peletier 1979) and possibly higher nutrient availability at mat sites given the very high mineralization rates in mangrove sediments (Bouillon et al. 2008).

The transect investigated in this study showed that bacterial biomass was not significantly higher in Beggiatoa mat sediments than in those without such mats. The limited contribution of Beggiatoa to total bacterial carbon was also suggested by differences in their respective $\delta^{13} \mathrm{C}$ values. Unlike other bacteria, Beggiatoa cells only have $2 \%$ of their biovolume consisting of active cytoplasm (Schulz \& Jørgensen 2001), and, as they are strongly vacuolated, they represent a considerably smaller amount of dry matter than suggested by their volume (Bernard \& Fenchel 1995). Beggiatoa biomass is consequently negligible compared to the total amount of bacteria found in the surficial sediment.

The concentration of bacteria in mats likely makes them easier for grazers to feed upon. However, none of the studied infaunal species exhibited a significantly higher abundance in Beggiatoa mat sediments. This constant abundance could hide changes in community composition, with an increased abundance of species specialized in Beggiatoa consumption. However, compartments linked with bacteria remain unchanged, and the general food-web structure is not strongly influenced by the presence of Beggiatoa. Similar enrichment levels in the ${ }^{13} \mathrm{C}$ of bacteria and ${ }^{13} \mathrm{C}$ of meiofauna suggest a constant contribution of bacteria to the diet of meiofauna along the transect. Consequently, complementary approaches utilizing natural and enriched stable isotopes suggest that the global bacterial food role is not increased by the presence of Beggiatoa. Most studies suggest that deep-sea microbial mats increase standing stocks of micro-, meio- and macrobenthic communities (Levin 2005). Isotopic data have revealed that the contribution of chemosynthetic carbon to the diet of benthic species increases with depth and the absence of photosynthetic primary production (Levin \& Michener 2002, Levin 2005). Despite this relationship with depth, sulfur-oxidizing bacteria can constitute an important food source in some shallow continental shelf systems (Powell et al. 1983, Montagna \& Spies 1985). Overall, mangrove forests are highly productive, with a large number of organic matter 
sources, such as labile leaf detritus and primary producers like diatoms and cyanobacteria. The mangrove system reveals that the additional trophic resource constituted by Beggiatoa does not influence infaunal abundances or the contribution of bacteria to their diet.

Infauna can be influenced by the toxicity of bacterial mat environments. Beggiatoa can create anoxic conditions as they can consume up to $70 \%$ of the total oxygen in the sediment (Fenchel \& Bernard 1995). Moreover, Beggiatoa are found in sediments rich in sulfide, which is toxic at low concentrations for many aerobic metazoans as it blocks the cytochrome $c$ oxidase of their respiratory chain (Bagarinao 1992). This toxicity is particularly high for small-sized grazers where diffusional fluxes of sulfide into body tissue are extremely fast (Jahn et al. 1997). Some meiofaunal species have developed a sulfide detoxification system based on the oxidation in their body wall (Fenchel \& Findlay 1995). However, this tolerance is restricted to certain species (Pape et al. 2011), and the diversity observed in bacterial mats is consequently often lower than in the adjacent sediment (Van Gaever et al. 2006). As a result, we suggest that in the studied marine mangrove systems, eukaryotic species able to tolerate this toxicity do not necessarily have a higher contribution of bacteria in their diets than species dwelling in the adjacent sediment.

Acknowledgements. P.-Y. Pascal conducted this research while being supported by a postdoctoral fellowship granted by the 'Région de la Guadeloupe' and the 'Fond Social Européen'. We thank Sébastien Cordonnier for his assistance in the field and Maeva Bouzat for her help in meiofaunal counting (Université des Antilles et de la Guyane), Lucienne Desfontaines (ASTRO - INRA Antilles-Guyane) for her help in preparing freeze-dried sediment samples, Célia Joaquim-Justo (Université de Liège) for identification of rotifers, Louise Firth (National University of Galway) for commenting upon and editing this manuscript and 3 anonymous reviewers for helpful comments. P.-Y. Pascal is very grateful to the 'Brigade Nautique de Gendarmerie de Pointe à Pitre' and to the medical staff of CHU of Pointe-à-Pitre for their efficient support after the barracuda attack he experienced in conducting fieldwork for this study.

\section{LITERATURE CITED}

Admiraal W, Peletier H (1979) Sulphide tolerance of benthic diatoms in relation to their distribution in an estuary. $\mathrm{Br}$ Phycol J 14:185-196

Bagarinao T (1992) Sulfide as an environmental factor and toxicant: tolerance and adaptations in aquatic organisms. Aquat Toxicol 24:21-62

Bernard C, Fenchel T (1995) Mats of colourless sulphur bacteria. II. Structure, composition of biota and successional patterns. Mar Ecol Prog Ser 128:171-179
Boschker HTS, Middelburg JJ (2002) Stable isotopes and biomarkers in microbial ecology. FEMS Microbiol Ecol 40:85-95

> Boschker HTS, Brouwer JFC, Cappenberg TE (1999) The contribution of macrophyte-derived organic matter to microbial biomass in salt-marsh sediments: stable carbon isotope analysis of microbial biomarkers. Limnol Oceanogr 44:309-319

Bouillon S, Borges AV, Castañeda-Moya E, Diele K and others (2008) Mangrove production and carbon sinks: a revision of global budget estimates. Global Biogeochem Cycles 22: GB2013, doi:10.1029/2007GB003052

de Jonge VN, Bouwman LA (1977) A simple density separation technique for quantitative isolation of meiobenthos using the colloidal silica Ludox-TM. Mar Biol 42:143-148

Elliott JK, Spear E, Wyllie-Echeverria S (2006) Mats of Beggiatoa bacteria reveal that organic pollution from lumber mills inhibits growth of Zostera marina. Mar Ecol 27: 372-380

Fenchel T, Bernard C (1995) Mats of colourless sulphur bacteria. I. Major microbial processes. Mar Ecol Prog Ser 128:161-170

Fenchel TM, Findlay BJ (1995) Ecology and evolution in anoxic worlds. Oxford University Press, Oxford

Fenchel T, Riedl RJ (1970) The sulfide system: a new biotic community underneath the oxidized layer of marine sand bottoms. Mar Biol 7:255-268

Finlay JC, Kendall C (2007) Stable isotope tracing a temporal and spatial variability in organic matter sources to freshwater ecosystems. In: Michener RH, Lajtha K (eds) Stable isotope in ecology and environmental science. Blackwell, Oxford, p 283-333

- Friedrich C, deSmet WH (2000) The rotifer fauna of Arctic sea ice from the Barents Sea, Laptev Sea and Greenland Sea. Hydrobiologia 432:73-89

Galván K, Fleeger JW, Fry B (2008) Stable isotope addition reveals dietary importance of phytoplankton and microphytobenthos to saltmarsh infauna. Mar Ecol Prog Ser 359:37-49

Gontikaki E, van Oevelen D, Soetaert K, Witte U (2011) Food web flows through a sub-arctic deep-sea benthic community. Prog Oceanogr 91:245-259

Güde H, Strohl WR, Larkin JM (1981) Mixotrophic and heterotrophic growth of Beggiatoa alba in continuous culture. Arch Microbiol 129:357-360

> Guilini K, Levin LA, Vanreusel A (2012) Cold seep and oxygen minimum zone associated sources of margin heterogeneity affect benthic assemblages, diversity and nutrition at the Cascadian margin (NE Pacific Ocean). Prog Oceanogr 96:77-92

> Hauquier F, Ingels J, Gutt J, Raes M, Vanreusel A (2011) Characterisation of the nematode community of a lowactivity cold seep in the recently ice-shelf free Larsen B area, Eastern Antarctic Peninsula. PLoS ONE 6:e22240

> Jahn A, Janas U, Theede H, Szaniawska A (1997) Significance of body size in sulphide detoxification in the Baltic clam Macoma balthica (Bivalvia, Tellinidae) in the Gulf of Gdansk. Mar Ecol Prog Ser 154:175-183

Joint IR, Gee JM, Warwick RM (1982) Determination of finescale vertical distribution of microbes and meiofauna in an intertidal sediment. Mar Biol 72:157-164

Kemp PF (1990) The fate of benthic bacterial production. Rev Aquat Sci 2:109-124

> Ladurner P, Schärer L, Salvenmoser W, Rieger RM (2005) A 
new model organism among the lower Bilateria and the use of digital microscopy in taxonomy of meiobenthic Platyhelminthes: Macrostomum lignano, n. sp. (Rhabditophora, Macrostomorpha). J Zool Syst Evol Res 43: 114-126

Larkin JM, Aharon P, Margaret C, Henk MC (1994) Beggiatoa in microbial mats at hydrocarbon vents in the Gulf of Mexico and warm mineral springs, Florida. Geo-Mar Lett 14:97-103

Levin LA (2005) Ecology of cold deep sediments: interactions of fauna with flow, chemistry and microbes. Oceanogr Mar Biol Annu Rev 43:1-46

> Levin LA, Michener RH (2002) Isotopic evidence for chemosynthesis-based nutrition of macrobenthos: the lightness of being at Pacific methane seeps. Limnol Oceanogr 47: 1336-1345

> Levin LA, Thomas CL, Whishner K (1991) Control of deepsea benthic community structure by oxygen and organicmatter gradients in the eastern Pacific Ocean. J Mar Res 49:763-800

Lloyd KG, Albert DB, Biddle JF, Chanton JP, Pizarro O, Teske A (2010) Spatial structure and activity of sedimentary microbial communities underlying a Beggiatoa spp. mat in a Gulf of Mexico hydrocarbon seep. PLoS ONE 5: e8738

Maurin L (2009) Ecologie des nématodes marins libres et symbiotiques en milieu tropical. Développement de la microspectrométrie Raman comme outil de caractérisation des organismes thiotrophiques. Universite des Antilles et de la Guyane, Saint-Claude

McCutchan JH, Lewis WM, Kendall C, McGrath CC (2003) Variation in trophic shift for stable isotope ratios of carbon, nitrogen, and sulfur. Oikos 102:378-390

- Middelburg JJ, Barranguet C, Boschker HTS, Herman PMJ, Moens T, Heip CHR (2000) The fate of intertidal microphytobenthos carbon. An in situ ${ }^{13} \mathrm{C}$ labelling study. Limnol Oceanogr 45:1224-1234

> Minagawa M, Wada E (1984) Stepwise enrichment of ${ }^{15} \mathrm{~N}$ along food chains: further evidence and the $\delta^{15} \mathrm{~N}$ and animal age. Geochim Cosmochim Acta 48:1135-1140

> Montagna PA, Spies RB (1985) Meiofauna and chlorophyll associated with Beggiatoa mats of a natural submarine petroleum seep. Mar Environ Res 16:231-242

Montagna PA, Bauer JE, Hardin D, Spies RB (1989) Vertical distribution of microbial and meiofaunal population in sediments of a natural coastal hydrocarbon seep. J Mar Res 47:657-680

Motoda S (1959) Devices of simple plankton apparatus. Mem Fac Fish Hokkaido Univ 7:73-94

> Pape E, Bezerra TN, Vanneste H, Heeschen K and others (2011) Community structure and feeding preference of nematodes associated with methane seepage at the Darwin mud volcano (Gulf of Cádiz). Mar Ecol Prog Ser 438: 71-83

> Parnell AC, Inger R, Bearhop S, Jackson AL (2010) Source partitioning using stable isotopes: coping with too much variation. PLoS ONE 5:e9672

> Pascal PY, Dupuy C, Haubois AG, Richard P, Niquil N (2008) Influence of environment factors on bacterial ingestion rate of the deposit-feeder Hydrobia ulvae and comparison with meiofauna. J Sea Res 60:151-156

Pascal PY, Dupuy C, Richard P, Mallet C, Armynot du

Editorial responsibility: Erik Kristensen,

Odense, Denmark
Chatelet E, Niquil N (2009) Seasonal variation in consumption of benthic bacteria by meio- and macrofauna in an intertidal mudflat. Limnol Oceanogr 54:1048-1059

> Pascal PY, Fleeger JW, Boschker HTS, Mitwally HM, Johnson DS (2013) Response of the benthic food web to shortand long-term nutrient enrichment in saltmarsh mudflats. Mar Ecol Prog Ser 474:27-41

Pascal PY, Bellemare C, Sterrer W, Boschker HTS, Gonzales-Rizzo S, Gros O (in press) Diet of Haplognathia ruberrima (Gnathostomulida) in a Caribbean marine mangrove. Mar Ecol

> Powell EN, Bright TJ, Woods A, Gitting S (1983) Meiofauna and thiobios in the East Flower Garden brine seep. Mar Biol 73:269-283

Powell EN, Bright TJ, Brooks JM (1986) The effect of sulfide and an increased food supply on the meiofauna and macrofauna at the East Flower Garden brine seep. Helgol Mar Res 40:57-82

Ramos LJ, Rocafort JLP, Miller MW (1995) Behavior patterns of the aplysiid gastropod Bursatella leachii in its natural habitat and in the laboratory. Neurobiol Learn Mem 63: 246-259

Salvadó H, Palomo A, Mas M, Puigagut J, Gracia M (2004) Dynamics of nematodes in a high organic loading rotating biological contactors. Water Res 38:2571-2578

Schärer L, Joss G, Sandner P (2004) Mating behaviour of the marine turbellarian Macrostomum sp.: These worms suck. Mar Biol 145:373-380

Schmid-Araya JM (1998) Rotifers in interstitial sediments. Hydrobiologia 387/388:231-240

Schulz HN, Jørgensen BB (2001) Big bacteria. Annu Rev Microbiol 55:105-137

Sherr EB, Sherr BF, Albright LJ (1987) Bacteria: sink or link? Science 235:88a-88

Sommer S, Gutzmann W, Ahlrichs W, Pfannkuche O (2003) Rotifers colonizing sediments with shallow gas hydrates. Naturwissenschaften 90:273-276

Sommer S, Gutzmann W, Pfannkuche O (2007) Sediments hosting gas hydrate: oases for metazoan meiofauna. Mar Ecol Prog Ser 337:27-37

Spies RB, DesMarais DJ (1983) Natural isotope study of trophic enrichment of marine benthic communities by petroleum seepage. Mar Biol 73:67-71

Sundbäck K, Nilsson P, Nilsson C, Jonsson B (1996) Balance between autotrophic and heterotrophic components and processes in microbenthic communities of sandy sediments: a field study. Estuar Coast Shelf Sci 43:689-706

> Van Gaever S, Moodley L, de Beer D, Vanreusel A (2006) Meiobenthos at the Arctic Håkon Mosby Mud Volcano, with a parental-caring nematode thriving in sulphiderich sediments. Mar Ecol Prog Ser 321:143-155

- van Oevelen D, Middelburg JJ, Soetaert K, Moodley L (2006a) The fate of bacterial carbon in sediments: modeling an in situ isotope tracer experiment. Limnol Oceanogr 51:1302-1314

> van Oevelen D, Moodley L, Soetaert K, Middelburg JJ (2006b) The trophic significance of bacterial carbon in a marine intertidal sediment: results of an in situ stable isotope labeling study. Limnol Oceanogr 51:2349-2359

> Zhukova NV, Kharlamenko VI (1999) Sources of essential fatty acids in the marine microbial loop. Aquat Microb Ecol 17:153-157

Submitted: March 6, 2014; Accepted: September 9, 2014 Proofs received from author(s): November 17, 2014 